\title{
Voltammetry of Irbesartan Drug in Pharmaceutical Formulations and Human Blood: Quantification and Pharmacokinetic Studies
}

\author{
Hanaa S. El-Desoky,* Mohamed M. Ghoneim and Allia. D. Habazy \\ Analytical \& Electrochemistry Research Unit, Chemistry Department, Faculty of Science, \\ Tanta University, 31527 Tanta, Egypt
}

\begin{abstract}
Voltamogramas cíclicos de 'irbesatan' em um eletrodo de gota pendente de mercúrio no tampão Britton-Robinson com valores de $\mathrm{pH}$ menores do que 4,5 exibiram um único pico catódico irreversível envolvendo dois elétrons, correspondendo à redução-saturação da ligação dupla $\mathrm{C}=\mathrm{N}$ de sua unidade tetrazólia. Na faixa de $\mathrm{pH}$ 4,5-5,5, os voltamogramas exibiram dois picos catódicos irreversíveis $\left(1^{\circ}\right.$ e $2^{\circ}$ picos $)$ com corrente de pico menor porém com alturas relativas iguais, as quais foram atribuídas à redução do grupo $\mathrm{C}=\mathrm{N}$ das formas ácida e básica de 'irbesatan', respectivamente. Um método voltamétrico de onda quadrada com redissolução anódica adsortiva foi desenvolvido para a quantificação de ibsertan total em solução. O método desenvolvido foi aplicado com sucesso na quantificação de 'ibsertan' em formulações farmacêuticas e soro humano enriquecido sem a necessidade de pré-tratamento de amostras e/ou etapas lentas de extração antes da análise. Foram obtidas interferências insignificantes de seu ingrediente ativo "hidroclorotiazida", excipientes, íons metálicos comuns e drogas co-administradas. Limites de detecção de $9,0 \times 10^{-10}$ e $2,1 \times 10^{-9} \mathrm{~mol} \mathrm{~L}^{-1}$ e limites de quantificação de $3,0 \times 10^{-9}$ e $7,0 \times 10^{-9} \mathrm{~mol} \mathrm{~L}^{-1}$ de 'irbesartan' total em padrão e em soro humano enriquecido foram alcançadas, respectivamente, pelo método voltamétrico desenvolvido. Além disto, parâmetros fármacocinéticos de 'irbesartan' em plasma de voluntários saudáveis obtidos após a administração oral de uma única dose de tabletes Aprovel® também foram estimados.
\end{abstract}

Cyclic voltammograms of irbesartan at the hanging mercury dropping electrode in the BrittonRobinson buffer of $\mathrm{pH}$ values lower than 4.5 exhibited a single 2-electron irreversible cathodic peak corresponding to the reduction-saturation of the $\mathrm{C}=\mathrm{N}$ double bond of its tetrazolyl moiety. Over the $\mathrm{pH}$ range 4.5-5.5, the voltammograms exhibited two irreversible cathodic peaks $\left(1^{\mathrm{st}}\right.$ and $2^{\text {nd }}$ peaks) of lower peak current but of relatively equal heights which were attributed to reduction of the $\mathrm{C}=\mathrm{N}$ group of the acidic and basic forms of irbesartan, respectively. A validated square-wave adsorptive cathodic stripping voltammetric method was developed for quantification of irbesartan in the bulk form. The developed stripping voltammetric method was successfully applied for quantitation of irbesartan in pharmaceutical formulations and spiked human serum, without the necessity for samples pretreatment and/or time-consuming extraction steps prior to the analysis. Insignificant interferences from its active ingredient "hydrochlorothiazide", excipients, common metal ions and co-administrated drugs were obtained during the analysis. Limits of detection of $9.0 \times 10^{-10}$ and $2.1 \times 10^{-9} \mathrm{~mol} \mathrm{~L}^{-1}$ and limits of quantitation of $3.0 \times 10^{-9}$ and $7.0 \times 10^{-9} \mathrm{~mol} \mathrm{~L}^{-1}$ irbesartan in the bulk form and in spiked human serum were achieved, respectively, by the developed stripping voltammetric method. Moreover, pharmacokinetic parameters of irbesartan in plasma of healthy volunteers following an oral administration of a single dose of Aprovel® tablets were also estimated.

Keywords: irbesartan, tablets, human blood, stripping voltammetry, pharmacokinetics

\section{Introduction}

Irbesartan, (Scheme 1), 2-butyl-3-[2-(1H-tetrazole-5-yl) (1,1-biphenyl)-4-yl]methyl]-1,3-diazaspiro[4,4]non-1-en-4one, is the first member of a chemical class of a non-peptide

*e-mail: hseldesoky@hotmail.com angiotensin II receptor antagonists (ARAII). Irbesartan and other ARAII receptor antagonists are used for the treatment of hypertension, diabetic nephropathy and heart failure. ${ }^{1}$ Irbesartan is metabolized mainly by glucuronidation (primarily on the tetrazole ring), hydroxylation, and additional oxidation to the inactive irbesartan glucuronide conjugate (approximately 6\%). ${ }^{1-3}$ Following oral administration of 
$150 \mathrm{mg}$ single dose of irbesartan, peak plasma concentration of irbesartan $\left(1.5 \pm 0.29 \mu \mathrm{g} \mathrm{mL}^{-1}\right)$ in human blood are attained at 1.5-2 $\mathrm{h}$ after dosing. The terminal elimination half-life of irbesartan averaged $11-15 \mathrm{~h}^{1-3}$

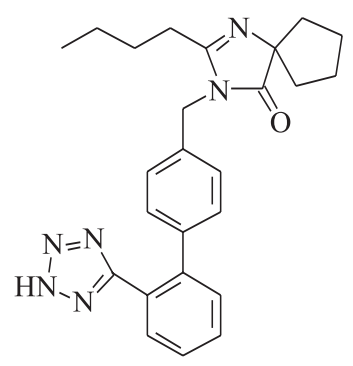

Scheme 1. Chemical structure of irbesartan molecule.

Many analytical methods were reported in the literature for determination of irbesartan in pharmaceutical formulations or in biological fluids. These include high performance liquid chromatography (HPLC), ${ }^{4-10}$ high-performance thinlayer chromatography (HPTLC),${ }^{11}$ liquid chromatographymass spectrometry (LC-MS), ${ }^{12}$ spectrophotometry, ${ }^{13-18}$ capillary electrophoresis ${ }^{19}$ and voltammetry. ${ }^{20,21}$ Almost all the reported methods have some drawbacks, lack in some validation parameters and necessitate time-consuming liquidliquid extraction steps prior to the analysis. On the other hand, in most of the reported HPLC methods for routine clinical analysis, a high-throughput analysis with expensive solid-phase extraction ${ }^{8-11}$ is always not advantageous as such equipment and techniques are not available in most of the laboratories. Moreover, the two reported voltammetric methods ${ }^{20,21}$ did not offer a sufficient sensitive quantification limit of irbesartan especially in pharmacokinetic studies. The first method ${ }^{20}$ has been described for determination of irbesartan in formulation using differential-pulse and squarewave voltammetric techniques at hanging mercury dropping electrode (HMDE) and in spiked human serum using squarewave voltammetric technique $\left(\mathrm{LOD}=6.14 \times 10^{-6} \mathrm{~mol} \mathrm{~L}^{-1}\right.$ $\left.\left(2.63 \mu \mathrm{g} \mathrm{mL}^{-1}\right)\right)$ but not in real plasma samples. Whereas, the second method ${ }^{21}$ has been described for determination of irbesartan in bulk form and formulation at the HMDE using DC, differential pulse, square wave, and first harmonic alternating current voltammetry. Quantitation limits of $1.33 \times 10^{-6} \mathrm{~mol} \mathrm{~L}^{-1}\left(0.57 \mu \mathrm{g} \mathrm{mL}^{-1}\right), 1.70 \times 10^{-6} \mathrm{~mol} \mathrm{~L}^{-1}$ $\left(0.73 \mu \mathrm{g} \mathrm{mL}^{-1}\right), 1.24 \times 10^{-6} \mathrm{~mol} \mathrm{~L}^{-1}\left(0.53 \mu \mathrm{g} \mathrm{mL} \mathrm{m}^{-1}\right)$ and $8.63 \times 10^{-7} \mathrm{~mol} \mathrm{~L}^{-1}\left(0.37 \mu \mathrm{g} \mathrm{mL} \mathrm{mL}^{-1}\right)$ irbesartan in bulk form were achieved, respectively. Because of the typical plasma concentrations reported in literature for healthy volunteers following administration of a single oral dose of $150 \mathrm{mg}$ irbesartan were in the range $(0.047 \pm 0.025$ to $\left.1.502 \pm 0.29 \mu \mathrm{g} \mathrm{mL}^{-1}\right)^{3}$ the reported voltammetric methods are considered not efficient enough for the assay of irbesartan at different therapeutic dose levels for pharmacokinetic studies as well as therapeutic drug monitoring. Besides, the electrochemical behavior of irbesartan studied on the mercury electrode by means of the two reported voltammetric methods ${ }^{20,21}$ still required more clarification. Pharmacokinetic parameters of irbesartan in human blood have also never been determined by any voltammetry method.

The aim of the present work was to develop a much sensitive square-wave adsorptive cathodic stripping voltammetric method for quantification of irbesartan in pharmaceutical formulations (in the absence and presence of the co-formulated drug 'hydrochlorothiazide') and human blood. Determination of pharmacokinetic parameters of irbesartan in human blood by means of the developed stripping voltammetric method was also a main aim of the present study. Besides, the electroreduction mechanism of irbesartan at the mercury electrode and determination of its $\mathrm{pk}_{\mathrm{a}}$ were also demonstrated.

\section{Experimental}

\section{Materials}

Bulk irbesartan and its pharmaceutical products namely "Aprovel ${ }^{\circledR}$ tablets" that claimed to contain $150 \mathrm{mg}$ irbesartan per tablet (Sanofi Pharma, Bristol-Myers Squibb SNC, Paris, France) and "Co-Aprovel ${ }^{\circledR}$ tablets" containing $300 \mathrm{mg}$ irbesartan and $12.5 \mathrm{mg}$ hydrochlorothiazide per tablet (Sanofi Pharma Bristol-Myers Squibb SNC, Paris, France), were investigated in the present work.

\section{Solutions}

\section{Bulk irbesartan solutions}

A standard stock solution $\left(1.0 \times 10^{-3} \mathrm{~mol} \mathrm{~L}^{-1}\right)$ of bulk irbesartan was prepared in methanol (Merck). Desired working solutions $\left(1.0 \times 10^{-8}-1.0 \times 10^{-4} \mathrm{~mol} \mathrm{~L}{ }^{-1}\right)$ were prepared by appropriate dilutions with methanol.

\section{Tablet solutions}

Ten Aprovel ${ }^{\circledR}$ tablets (150 mg irbesartan per tablet) and ten Co-Aprovel ${ }^{\circledR}$ tablets (a binary mixture labeled to contain $300 \mathrm{mg}$ irbesartan and $12.5 \mathrm{mg}$ hydrochlorothiazide per tablet) were weighed separately and the average mass per tablet was determined, and then grounded to fine powders. A weighed portion of each of the homogeneous powders equivalent to $1.0 \times 10^{-3} \mathrm{~mol} \mathrm{~L}^{-1}$ irbesartan was accurately transferred into $100 \mathrm{~mL}$ volume calibrated flask containing $70 \mathrm{~mL}$ methanol (Merck). The content of each flask was sonicated for about $10 \mathrm{~min}$ and then filled up with methanol. Each of the prepared solutions was then filtered through 
$0.45 \mu \mathrm{m}$ Milli-pore filter (Gelman, Germany). Convenient concentrations of irbesartan were then obtained by accurate dilution of the obtained solutions with methanol.

\section{Spiked serum solutions}

Serum samples of two healthy volunteers were mixed and then stored at $-20{ }^{\circ} \mathrm{C}$ until analysis. Into each of 10 centrifugation tubes $(3 \mathrm{~mL}$ polypropylene microcentrifuge tubes) containing a certain concentration of irbesartan, $100 \mu \mathrm{L}$ volume of the human serum was transferred, then mixed well with $1 \mathrm{~mL}$ of methanol to denature and precipitate of proteins. The solutions were centrifuged using an Eppendorf centrifuge (Hamburg, Germany) for 3 min at $14000 \mathrm{rpm}$ to separate out the precipitated proteins. The clear supernatant layers of these solutions were filtered through $0.45 \mu \mathrm{m}$ Milli-pore filters to produce protein-free human serum samples spiked with various concentrations of irbesartan $\left(1.0 \times 10^{-8}-1.0 \times 10^{-4} \mathrm{~mol} \mathrm{~L}^{-1}\right)$.

\section{Supporting electrolytes}

A series of the Britton-Robinson (B-R) universal buffer of $\mathrm{pH}$ 2-11 and acetate buffer of $\mathrm{pH}$ 3.8-6.3 were prepared in de-ionized water and used as supporting electrolytes. All the chemicals used were of analytical-reagent grade quality. A pH-meter (Crison, Barcelona, Spain) was used for the $\mathrm{pH}$ measurements.

\section{Pharmacokinetic studies}

Two healthy male volunteers (45-50 years old) took part in this study. Both were healthy, since they had normal heart, liver and kidney functions. Subjects were caffeine and alcohol free for at least $12 \mathrm{~h}$ before the administration of the drug. The two volunteers gave their written informed consent prior to anticipating in the study (at Ramadan Specialized Hospital, Tanta City, Egypt). Each subject received a single $150 \mathrm{mg}$ oral dose of irbesartan (Aprovel ${ }^{\circledR}$ tablet) in the morning, after an overnight fast. Blood samples ( $100 \mu \mathrm{L}$ each) were obtained at 0 (pre-dose), $0.5,1$, $1.5,2,3,4,8,12$ and $24 \mathrm{~h}$ after the oral administration. The blood samples were centrifuged immediately at $3000 \mathrm{rpm}$ for $15 \mathrm{~min}$ and then the plasma fractions were rapidly separated and stored in coded polypropylene tubes at $-20{ }^{\circ} \mathrm{C}$ until the assay. Following separation of proteins by methanol and then separation by centrifugation, the plasma samples were analyzed using the developed SW-AdCSV.

\section{Apparatus}

Computer-controlled Potentiostats Models 263A and 394-PAR (Princeton Applied Research, Oak Ridge,
USA) with the software 270/250-PAR were used for the voltammetric measurements. An electrode assembly (303A-PAR) incorporated with a micro-electrolysis cell and a three-electrode configuration system comprising of a $\mathrm{HMDE}$ as a working electrode (area of $\mathrm{HMDE}=0.026 \mathrm{~cm}^{2}$ ), an $\mathrm{Ag} / \mathrm{AgCl} / \mathrm{KCl}_{\mathrm{s}}$ reference electrode and a platinum wire auxiliary electrode, was used.

\section{Procedure}

A known volume of the analyte solution was pipetted into $10 \mathrm{~mL}$ volume calibrated flask and then filled up with the supporting electrolyte of the selected $\mathrm{pH}$ value. This solution was introduced quantitatively into the electrolysis cell, and then deoxygenated with pure nitrogen gas for about $5 \mathrm{~min}$ in the first cycle and for $30 \mathrm{~s}$ in each successive cycle, while a stream of nitrogen gas was kept over the solution during the measurements. In stripping voltammetric analysis, preconcentration of irbesartan onto the surface of HMDE was performed by adsorptive accumulation at $-0.3 \mathrm{~V}\left(v s . \mathrm{Ag} / \mathrm{AgCl} / \mathrm{KCl}_{\mathrm{s}}\right.$ ) for $110 \mathrm{~s}$ while stirring the solution at $400 \mathrm{rpm}$. After equilibrium time of $5 \mathrm{~s}$ allowed for the solution to become quiescent, the voltammograms were recorded by scanning the potential towards negative direction using square-wave potential waveform.

\section{Results and Discussion}

\section{Electroreduction of irbesartan}

Cyclic voltammograms of $1.0 \times 10^{-4} \mathrm{~mol} \mathrm{~L}^{-1}$ irbesartan solution in the B-R universal buffers of $\mathrm{pH}$ values lower than 4.5 exhibited a single 2-electron irreversible cathodic peak. As the $\mathrm{pH}$ of the medium has increased, the peak current has sharply decreased, Figure 1. In buffers of $\mathrm{pH}$ values 4.5-5.5, this peak splits into two peaks ( $1^{\text {st }}$ and $2^{\text {nd }}$ splitting peaks) with lower current but of relatively equal heights. At $\mathrm{pH}$ values higher than 5.5 the $2^{\text {nd }}$ splitting peak disappeared completely and the voltammograms exhibited again a single irreversible cathodic peak. Irbesartan molecule possesses imidazole and tetrazolyl groups; the imidazole group is known to be electro-inactive at the mercury electrode in aqueous media; however it is reducible at a platinum electrode in non-aqueous media. ${ }^{22}$ On the other hand, the $\mathrm{N}=\mathrm{N}$ group in most organic compounds is known to be reduced much easier than $\mathrm{C}=\mathrm{N}$ one. ${ }^{23-25}$ So, considering the reduction potentials of irbesartan over the entire $\mathrm{pH}$ range, the reduction behavior of irbesartan on HMDE may be attributed to saturation of the azomethine group $\mathrm{C}=\mathrm{N}$ in tetrazolyl moiety of irbesartan molecule ${ }^{26}$ not to the $\mathrm{N}=\mathrm{N}$ group which is in contradictory to that reported in literature..$^{21}$ 


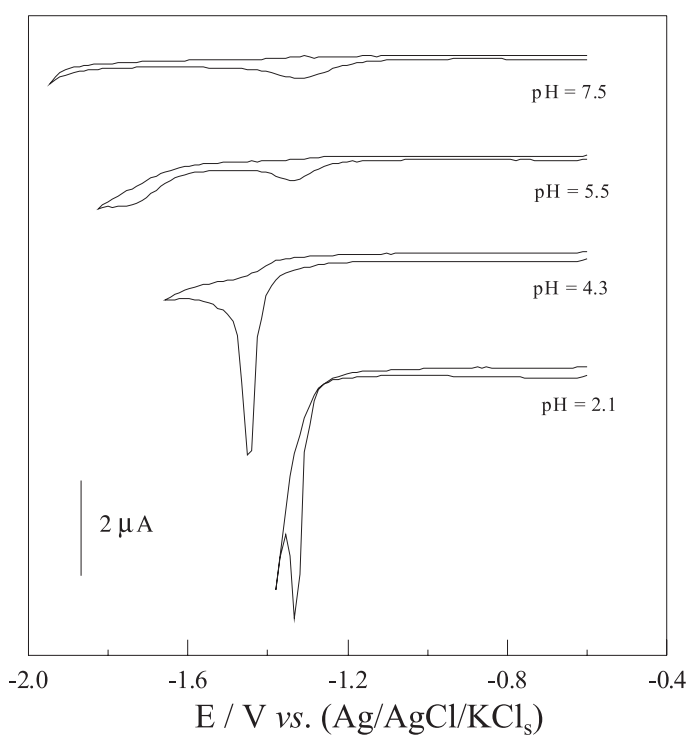

Figure 1. Cyclic voltammograms of $1.0 \times 10^{-4} \mathrm{~mol} \mathrm{~L}^{-1}$ irbesartan in the B-R universal buffer of different $\mathrm{pH}$ values containing $10 \%(\mathrm{v} / \mathrm{v})$ methanol; scan rate $=200 \mathrm{mV} \mathrm{s}^{-1}$.

Plot of the peak current of the single cathodic peak $(\mathrm{pH}$ values lower than 4.5$)$ and the $1^{\text {st }}$ splitting one ( $\left.\mathrm{pH} 4.5-8\right)$ versus $\mathrm{pH}$ recalls a dissociation curve ( $Z$-shaped curve), Figure 2, which may be due to the presence of irbesartan species in an acid (AH)-base ( $\left.\mathrm{A}^{-}\right)$equilibrium. ${ }^{27}$ Also angiotensin II receptor antagonist compounds have acidbase and tautomerism properties ${ }^{27,28}$ due to the tetrazole functional groups $\left(\mathrm{pK}_{\mathrm{a}}\right.$ of tetrazole $\left.=4.89\right) .{ }^{29} \mathrm{The} \mathrm{pH}$ value corresponding to the half-height of the plot of $\mathrm{i}_{\mathrm{p}}$ versus $\mathrm{pH}$ (Figure 2) or to the peak of $\delta_{\mathrm{p}} / \delta \mathrm{pH}$ versus $\mathrm{pH}$ plot (Figure 2, inset) equals the $\mathrm{pK}_{\mathrm{a}}$ of irbesartan $\left(\mathrm{pH}=\mathrm{pK}_{\mathrm{a}}=4.7\right)$. This value agrees well with those reported in the literature for $\mathrm{pK}_{\mathrm{a}}$ of irbesartan (4.5-4.7 \pm 0.06$)^{7,27}$ and different angiotensin II receptor antagonists $(4.0 \pm 0.9)^{27}$ which is attributed to the deprotonation of the tetrazolyl group.

On the other hand, on the increase of $\mathrm{pH}$ of the medium the peak potential of the single peak ( $\mathrm{pH}$ values lower than 4.5) shifts towards more negative values. This behavior confirmed the involvement of protons in the electrode reaction in solutions of $\mathrm{pH}$ values lower than 4.5 and that the proton-transfer reaction precedes the electron transfer process. ${ }^{30}$ Whereas, the peak potentials of $1^{\text {st }}$ and $2^{\text {nd }}$ splitting peaks are $\mathrm{pH}$-independent. A rectilinear plot of the peak potential $\mathrm{E}_{\mathrm{p}}$ versus $\mathrm{pH}$ for the single peak ( $\mathrm{pH}$ values lower than 4.5) was obtained; its corresponding regression equation was: $\mathrm{E}_{\mathrm{p}}(\mathrm{V})=0.053 \mathrm{pH}+1.15(\mathrm{r}=0.997$ and $\mathrm{n}=6)$.

The irreversible nature of the reduction process of irbesartan was confirmed by the shift of the peak potential $\left(\mathrm{E}_{\mathrm{p}}\right.$ ) of its single cathodic peak ( $\mathrm{pH}$ values lower than 4.5) to more negative values with the increase of scan rate (25 to $\left.500 \mathrm{mV} \mathrm{s}^{-1}\right) .31,32$ Plot of peak potential $\left(\mathrm{E}_{\mathrm{p}}\right)$ of the single

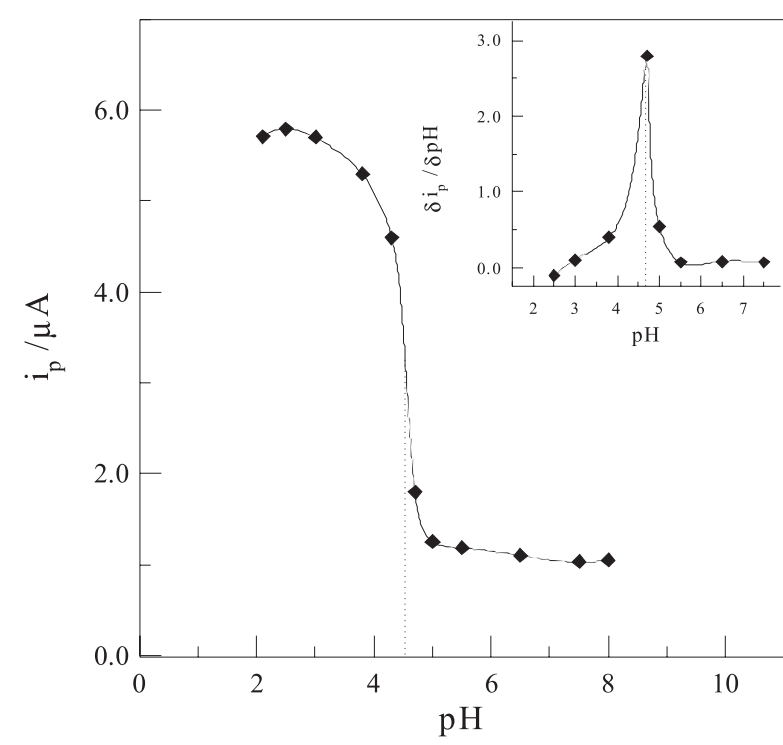

Figure 2. Plots of $\mathrm{i}_{\mathrm{p}}$ versus $\mathrm{pH}$ and $\delta \mathrm{i}_{\mathrm{p}} / \delta \mathrm{pH}$ versus $\mathrm{pH}$ (inset) of the single peak ( $\mathrm{pH}$ values lower than 4.5) and $1^{\text {st }}$ splitting peak $(\mathrm{pH} 4.5-8)$ of $1.0 \times 10^{-4} \mathrm{~mol} \mathrm{~L}^{-1}$ irbesartan.

cathodic peak in solution of $\mathrm{pH} 2.1$ versus logarithm of scan rate $(v)$ was linear; its corresponding regression equation was: $\mathrm{E}_{\mathrm{p}}(\mathrm{V})=0.027 \log v+0.32(\mathrm{r}=0.999$ and $\mathrm{n}=5)$. According to Nicholson and Greef ${ }^{31,32}$ values of $\alpha_{\mathrm{a}}$ of 1.10 and $\alpha$ of 0.55 (for $\mathrm{n}_{\mathrm{a}}=2$ ) were estimated from slope value of the obtained $\mathrm{E}_{\mathrm{p}}$ versus $\log v$ plot $\left(59 / 2 \alpha \mathrm{n}_{\mathrm{a}}=27 \mathrm{mV}\right)$, confirming the irreversible nature of the electrode process of irbesartan at the HMDE.

According to the foregoing results the electro-reduction of the $\mathrm{C}=\mathrm{N}$ center of irbesartan molecule on the mercury electrode in solutions of $\mathrm{pH}$ values lower than 4.5 (reaction i) and at $\mathrm{pH}$ values of 4.5 and higher (reactions ii and iii) can be expressed as illustrated in Scheme 2.

In solutions of $\mathrm{pH}$ values 4.5 and higher irbesartan molecule was found to be in an acid-base equilibrium $\left(\mathrm{pK}_{\mathrm{a}}=4.7\right)$. Both the acidic $(\mathrm{AH})$ and basic $\left(\mathrm{A}^{-}\right)$forms are electro-active. Thus, the electrode reaction of irbesartan over the $\mathrm{pH}$ range 4.5 and higher takes place via two steps attributed to reduction of both the acidic form $\left(1^{\text {st }}\right.$ splitting peak) and basic one ( $2^{\text {nd }}$ splitting peak). However, the $2^{\text {nd }}$ peak disappeared at $\mathrm{pH}$ higher than 5.5 which may be due to the intense electron density of its tetrazole ring; its reduction peak is difficult to appear in the accessible potential range.

\section{Adsorptive behavior of irbesartan}

Cyclic voltammogram of $1.0 \times 10^{-6} \mathrm{~mol} \mathrm{~L}^{-1}$ irbesartan at $100 \mathrm{mV} \mathrm{s}^{-1}$ in the B-R universal buffer of $\mathrm{pH} 4$ and in the acetate buffer of $\mathrm{pH} 4$ recorded following its preconcentration onto the HMDE by adsorptive accumulation under open 


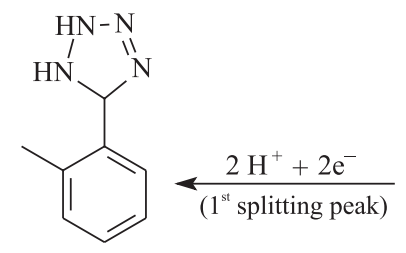

(ii) In solutions of $\mathrm{pH}$ values 4.5 and higher

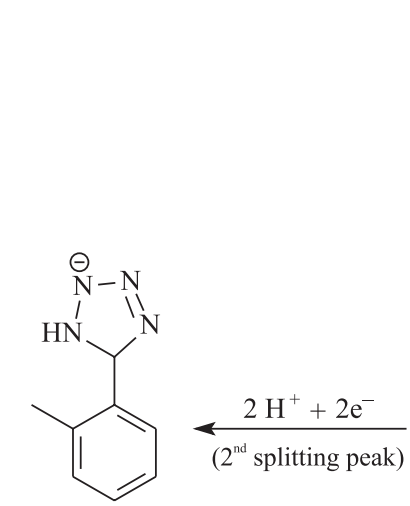

(iii) In solutions of $\mathrm{pH}$ values 4.5 and higher<smiles>Cc1ccccc1-c1nn[nH]n1</smiles>

$\mathrm{AH}$

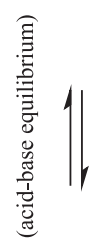

(N)

$A^{-}$

Scheme 2. Electrode reaction of irbesartan at the HMDE.

circuit conditions (e.g., Figure 3, curve a) exhibited a low peak current magnitude. On recording the cyclic voltammogram of the same solution following preconcentration of irbesartan onto the HMDE by adsorptive accumulation at $-0.3 \mathrm{~V}$ (versus $\mathrm{Ag} / \mathrm{AgCl} / \mathrm{KCl}_{\mathrm{s}}$ ) for $30 \mathrm{~s}$ (Figure 3, $1^{\text {st }}$ cycle $\mathrm{b}$ and $2^{\text {nd }}$ cycle $c$ ) the peak current magnitude $\left(i_{p}\right)$ was enhanced in the $1^{\text {st }}$ cycle (Figure 3 , curve b) indicating its adsorption onto surface of the HMDE.

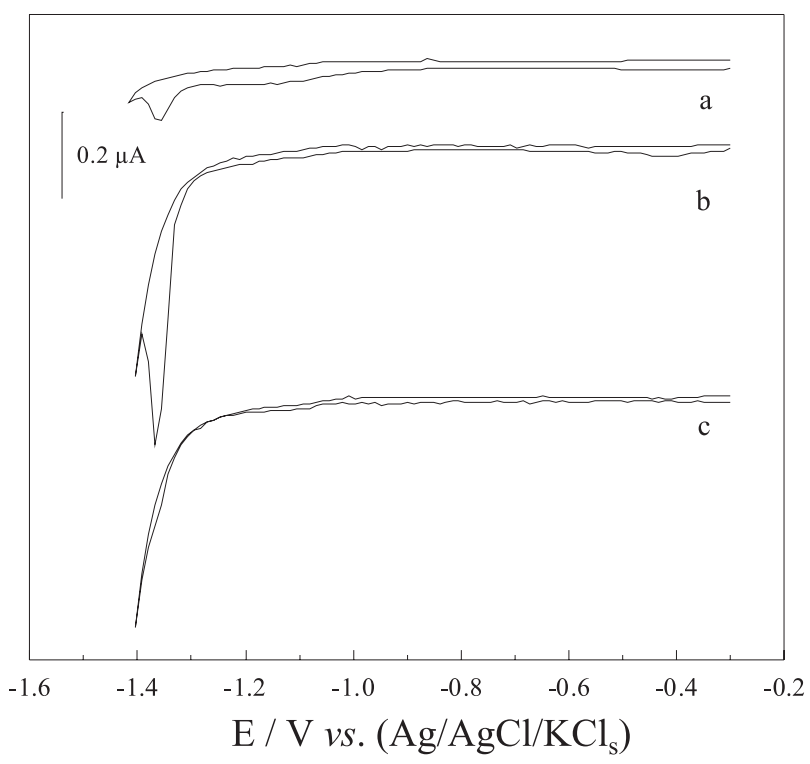

Figure 3. Cyclic voltammograms of $1.0 \times 10^{-6} \mathrm{~mol} \mathrm{~L}^{-1}$ irbesartan in the acetate buffer $(\mathrm{pH} 4)$ recorded following its preconcentration onto the HMDE by adsorptive accumulation under open circuit conditions (a) and at $\mathrm{E}_{\text {acc }}=-0.3 \mathrm{~V}$ for $30 \mathrm{~s}\left(1^{\text {st }}\right.$ cycle $\mathrm{b}$ and $2^{\text {nd }}$ cycle $\left.\mathrm{c}\right)$; scan rate $=100 \mathrm{mV} \mathrm{s}^{-1}$.

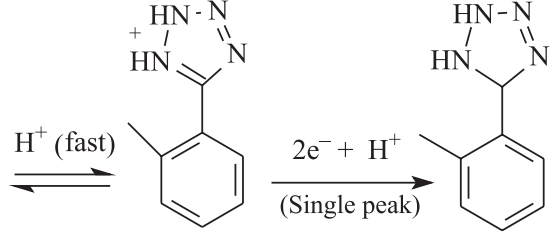

(i) In solutions of $\mathrm{pH}$ values lower than 4.5
On the other side, the peak current magnitude increased linearly upon the increase of scan rate $v\left(25\right.$ to $\left.500 \mathrm{mV} \mathrm{s}^{-1}\right)$. Linear plots of $\log \mathrm{i}_{\mathrm{p}}$ versus $\log v$ were obtained with slope values of 0.80 and 0.95 in the B-R universal and acetate buffers of $\mathrm{pH} \mathrm{4}$, respectively. The latter is very close to the expected theoretical value (1.0) for an ideal reaction of surface species. ${ }^{33}$

The electrode surface coverage $\left(\Gamma^{o} \mathrm{~mol} \mathrm{~cm}{ }^{-2}\right)$ in the acetate buffer of $\mathrm{pH} 4$ was calculated using the equation $\Gamma^{\circ}=\mathrm{Q} / \mathrm{nFA}$, where $\mathrm{Q}$ is the charge consumed by the surface process as estimated by the integration of the area under peak of cyclic voltammogram, $\mathrm{n}$ is the number of electrons consumed in the reduction process $(n=2), F$ is the Faraday's constant $(96,487 \mathrm{C})$ and A is the electrode surface area $\left(0.026 \mathrm{~cm}^{2}\right)$. On dividing the number of coulombs transferred, $0.7966 \mu \mathrm{C}$, by the conversion factor nFA $\left(5017.324 \times 10^{6} \mu \mathrm{C}\right)$, a monolayer surface coverage of $1.59 \times 10^{-10} \mathrm{~mol} \mathrm{~cm} \mathrm{~cm}^{-2}$ was estimated. Each adsorbed irbesartan molecule therefore occupied an area of $1.04 \mathrm{~nm}^{2}$.

\section{Quantification studies}

\section{Optimization of SW-AdCS voltammetric method}

Based on the adsorption behavior of irbesartan onto the mercury electrode surface, square-wave adsorptive cathodic stripping voltammetry (SW-AdCSV) method was optimized for its trace quantitation in the bulk form. SW-AdCS voltammograms of bulk irbesartan in the B-R universal buffer (pH 2 to 7) and in acetate buffer (pH 3.8 to 6.3) recorded 
following its preconcentration onto the HMDE by adsorptive accumulation for $30 \mathrm{~s}$ at $-0.4 \mathrm{~V}$ exhibited a well-defined single irreversible cathodic peak. A better enhanced peak current magnitude was achieved in the acetate buffer of $\mathrm{pH} 4$. Therefore, acetate buffer of $\mathrm{pH} 4$ was chosen as a supporting electrolyte for the rest of the analytical study.

Effect of preconcentration potential $\left(\mathrm{E}_{\text {acc. }}\right)$ of 0.0 to $-1.0 \mathrm{~V}$ (versus $\mathrm{Ag} / \mathrm{AgCl} / \mathrm{KCl}_{\mathrm{s}}$ ) on the $\mathrm{SW}$-AdCSV peak current magnitude of $1.0 \times 10^{-7} \mathrm{~mol} \mathrm{~L}^{-1}$ irbesartan was examined in the acetate buffer of $\mathrm{pH} 4$ following its preconcentration onto the HMDE by adsorptive accumulation for $30 \mathrm{~s}$. At a preconcentration potential of $-0.3 \mathrm{~V}$ a better enhanced peak current magnitude was achieved; therefore it was chosen for further studies. Influence of the pulse parameters namely: frequency f (10 to $120 \mathrm{~Hz})$, scan increment $\Delta \mathrm{E}$ ( 2 to $12 \mathrm{mV}$ ) and pulse-amplitude a (10 to $100 \mathrm{mV}$ ) on the SW-AdCSV peak current magnitude of $1.0 \times 10^{-7} \mathrm{~mol} \mathrm{~L}^{-1}$ irbesartan in the acetate buffer of $\mathrm{pH} 4$ recorded following preconcentration by adsorptive accumulation onto the HMDE at $\mathrm{E}_{\text {acc. }}=-0.3 \mathrm{~V}$ for $30 \mathrm{~s}$ was examined. A better developed and symmetrical voltammetric peak was obtained at the following pulse parameters: $\mathrm{f}=120 \mathrm{~Hz}, \Delta \mathrm{E}_{\mathrm{s}}=12 \mathrm{mV}$ and, $\mathrm{a}=25 \mathrm{mV}$. Also effect of varying the preconcentration time $\left(\mathrm{t}_{\text {acc. }}\right)$ on the voltammetric peak current magnitude of various concentrations of bulk irbesartan $\left(1.0 \times 10^{-6}\right.$, $1.0 \times 10^{-7}$ and $\left.1.0 \times 10^{-8} \mathrm{~mol} \mathrm{~L}^{-1}\right)$ in the acetate buffer of $\mathrm{pH} 4$ was evaluated. As shown in Figure (4), for $1.0 \times 10^{-6}$ and $1.0 \times 10^{-7} \mathrm{~mol} \mathrm{~L}^{-1}$ bulk irbesartan, the response was linear up to 40 and $110 \mathrm{~s}$, respectively, and then leveled off. While for $1.0 \times 10^{-8} \mathrm{~mol} \mathrm{~L}^{-1}$ irbesartan, as the accumulation time was increased, linearity was prevailed over all the tested accumulation time. The influence of the rest time was also considered and a time period of $5 \mathrm{~s}$ was chosen. On the other hand, the square-wave signal was found to increase as the area of the HMDE was increased $\left(0.01\right.$ to $\left.0.026 \mathrm{~cm}^{2}\right)$; therefore, the present study was carried out at a HMDE area of $0.026 \mathrm{~cm}^{2}$. The results revealed that the optimal conditions of the developed SW-AdCSV method which generated a well-shaped and a better enhanced peak current magnitude were: $\mathrm{E}_{\text {acc }}=-0.3 \mathrm{~V}, \mathrm{t}_{\text {acc. }} \leq 110 \mathrm{~s}$ (depending on the sensitivity required), $\mathrm{f}=120 \mathrm{~Hz}, \Delta \mathrm{E}_{\mathrm{s}}=12 \mathrm{mV}, \mathrm{a}=25 \mathrm{mV}$ and the acetate buffer of $\mathrm{pH} 4$ as a supporting electrolyte.

Using the developed SW-AdCSV method for assay of standard solutions of various concentrations of irbesartan, a linear calibration curve was obtained over the concentration range of $3.0 \times 10^{-9}$ to $5.0 \times 10^{-7} \mathrm{~mol} \mathrm{~L}^{-1}$ irbesartan; the corresponding regression equation was: $\mathrm{i}_{\mathrm{p}}(\mu \mathrm{A})=66.58 \mathrm{C}(\mu \mathrm{mol} \mathrm{L}-1)+1.76(\mathrm{r}=0.991$ and $\mathrm{n}=6)$. Limits of detection (LOD) and quantitation (LOQ) of $9 \times 10^{-10} \mathrm{~mol} \mathrm{~L}^{-1}\left(3.86 \times 10^{-4} \mu \mathrm{g} \mathrm{mL} \mathrm{m}^{-1}\right)$ and $3 \times 10^{-9} \mathrm{~mol} \mathrm{~L}^{-1}$ $\left(1.28 \times 10^{-3} \mu \mathrm{g} \mathrm{mL^{-1 }}\right)$ of bulk irbesartan, respectively, were

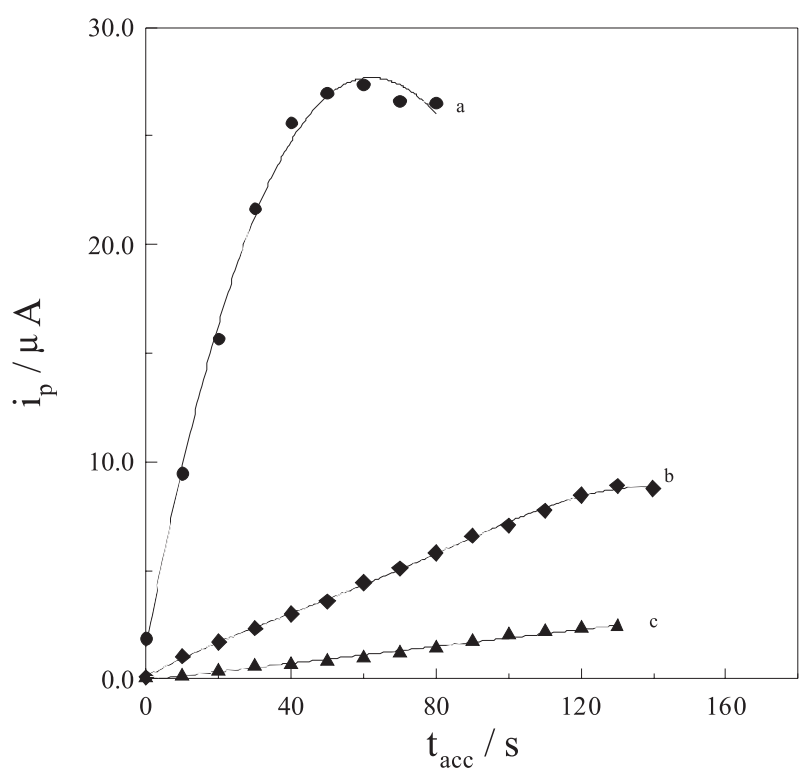

Figure 4. Plots of SW-AdCSV peak current (i $)$ versus preconcentration time $\left(\mathrm{t}_{\text {acc }}\right)$ of (a) $1 \times 10^{-6}$, (b) $1 \times 10^{-7}$ and (c) $1 \times 10^{-8} \mathrm{~mol} \mathrm{~L}^{-1}$ bulk irbesartan recorded following its preconcentration onto the HMDE by adsorptive accumulation at $\mathrm{E}_{\mathrm{acc}}=-0.3 \mathrm{~V}$ in the acetate buffer of $\mathrm{pH} 4 ; \mathrm{f}=120 \mathrm{~Hz}$, $\mathrm{a}=25 \mathrm{mV}$ and $\Delta \mathrm{E}_{\mathrm{s}}=12 \mathrm{mV}$.

estimated using the expression: $\mathrm{k}$ SD $/ \mathrm{b},{ }^{34}$ where $\mathrm{k}=3$ for LOD and 10 for LOQ, SD is the standard deviation of the blank and $\mathrm{b}$ is the slope of the calibration curve.

\section{Interferences validation method}

The interferences from excipients in determination of irbesartan ${ }^{35}$ by the developed analytical method were evaluated. This was performed by analysis of $1.0 \times 10^{-8} \mathrm{~mol} \mathrm{~L}^{-1}$ bulk irbesartan solution by the developed SW-AdCSV in the absence and in presence of the common excipients (such as microcrystalline cellulose, croscarmellose sodium, lactose monohydrate, hypromellose, silicon dioxide, magnesium stearate, titanium dioxide (E 171), macrogol, carnauba wax, pregelatinized starch and poloxamer 188). The differences in main percentage recoveries $(\% \mathrm{R})$ and the relative standard deviations (RSD\%) obtained by means of the developed SW-AdCSV method were insignificant, since $\% \mathrm{R} \pm \mathrm{RSD}$ in the absence of excipients and in their presence were $99.43 \pm 1.38$ and $98.66 \pm 2.24$, respectively. The results suggested the successful determination of irbesartan by the developed SW-AdCSV method with insignificant interferences from excipients.

\section{Reproducibility, accuracy and precision}

These were examined by performing three replicate analysis of standard solutions of bulk irbesartan by the developed SW-AdCSV method over one day (intra-day 
assay) and for three successive days (inter-day assay). ${ }^{35}$ The mean percentage recovery $(\% \mathrm{R})$ was calculated as a percent of the nominal concentrations in the standard solutions. Accuracy was expressed as relative error (RE\%) while precision was assessed from the relative standard deviation in percentage (RSD\%) of the mean recovery. The mean percentage recoveries ( $\% \mathrm{R})$ and relative standard deviations $(\mathrm{RSD} \%)$ shown in Table (1), indicated the high precision and accuracy of the developed SW-AdCSV method for assay of irbesartan.

Table 1. Analytical precision and accuracy of determination of $1.0 \times 10^{-7} \mathrm{~mol} \mathrm{~L}^{-1}$ bulk irbesartan by the developed SW-AdCSV method $(n=3)$

\begin{tabular}{cccccc}
\hline & intra-day & & \multicolumn{3}{c}{ inter-day } \\
& & & \multicolumn{3}{c}{ (Over three successive days) } \\
Recovery & Accuracy & Precision & Recovery & Accuracy & Precision \\
$\%$ R & RE\% & RSD\% & $\%$ R & RE\% & RSD \% \\
\hline 101.29 & 1.29 & 0.51 & 100.98 & 0.98 & 0.37 \\
& & & 99.98 & -0.17 & 0.41 \\
& & & 98.20 & -2.17 & 1.87 \\
\hline
\end{tabular}

\section{Robustness and inter-laboratory precision}

In regard to the robustness ${ }^{35}$ of measurements by the developed SW-AdCSV method, influence of small variation of some of the neck operational conditions including $\mathrm{pH}$ (3.8 to 4.2$)$ of the medium, preconcentration potential $(-0.35$ to $-0.45 \mathrm{~V}$ ) and time (100 to $120 \mathrm{~s}$ ), on $\% \mathrm{R}$ and $\mathrm{RSD} \%$ of $5 \times 10^{-8} \mathrm{~mol} \mathrm{~L}^{-1}$ bulk irbesartan was studied. The obtained mean $\% \mathrm{R} \pm \mathrm{RSD}(101.02 \pm 0.31$ to $98.55 \pm 0.88)$ indicated insignificant effect within the studied range of variation of the optimum operational conditions, and consequently the developed SW-AdCSV method was reliable for assay of bulk irbesartan and it could be considered robust.

The inter-laboratory precision ${ }^{35}$ of measurements by the developed SW-AdCSV method was examined by assay of $5.0 \times 10^{-8} \mathrm{~mol} \mathrm{~L}^{-1}$ irbesartan using two PAR- PotentiostatsModels 263A (Lab 1) and 273 (Lab 2) under the same operational conditions at different elapsed times by two different analysts. The mean percentage recoveries obtained at Lab $1(99.85 \pm 0.2)$ to Lab $2(97.58 \pm 0.87)$ were found reproducible.

\section{Applications}

\section{Analysis of Aprovel ${ }^{\circledR}$ and Co-Aprovel ${ }^{\circledR}$ tablets}

The developed SW-AdCSV method was successfully applied for analysis of irbesartan in "Aprovel ${ }^{\circledR}$ " and in "Co-Aprovel ${ }^{\circledR ”}$ tablets, without the necessity for extraction of the drug prior to the analysis using both the calibration curve and standard addition methods. ${ }^{36}$ It is worth mentioning that no peak due to hydrochlorothiazide alone has been detected under the optimum operational conditions. Mean percentage recoveries obtained for analysis of $5.0 \times 10^{-8} \mathrm{~mol} \mathrm{~L}^{-1}$ irbesartan in standard solutions of Aprovel ${ }^{\circledR}$ and Co-Aprovel ${ }^{\circledR}$ tablets by the developed SW-AdCSV method were statistically compared with that obtained by a reported HPTLC method ${ }^{11}$ (Table 2). The calculated F-value did not exceed the theoretical one (Table 2), indicating the insignificant difference in reproducibility ${ }^{37}$ of the developed analytical method and that of the reported HPTLC one. ${ }^{11}$ Also, insignificant difference was noticed between the described SW-AdCSV method and the reported one ${ }^{11}$ regarding accuracy and precision as revealed by $t$-test ${ }^{37}$ (Table 2). These results confirmed that the developed SW-AdCSV method can be applied successfully for analysis of irbesartan in formulations without interferences either from excipients or co-formulated drug "hydrochlorothiazide".

Table 2. Assay of $5.0 \times 10^{-8} \mathrm{~mol} \mathrm{~L}^{-1}$ standard solutions of irbesartan in "Aprovel ${ }^{\circledR}$ tablets" (150 mg irbesartan / tablet) and "Co-Aprovel ${ }^{\circledast}$ tablets" (300 mg irbesartan $+12.5 \mathrm{mg}$ hydrochlorothiazide) by means of the developed SW-AdCSV and by a reported $\operatorname{HPTLC}^{11}$ methods $(\mathrm{n}=4)$

\begin{tabular}{|c|c|c|c|}
\hline \multirow[t]{2}{*}{ Sample } & \multicolumn{2}{|c|}{$(\% \mathrm{R} \pm \mathrm{RSD})$} & \multirow{2}{*}{$\begin{array}{l}\text { F-value } \\
\text { and } t \text {-test } \mathrm{t}^{\mathrm{a}}\end{array}$} \\
\hline & SW-AdCSV & HPTLC $^{11}$ & \\
\hline $\begin{array}{l}\text { Aprovel@ tablets } \\
\text { (A) }\end{array}$ & $99.73 \pm 0.78$ & $99.54 \pm 0.87$ & 1.24 and 1.21 \\
\hline (B) & $99.32 \pm 0.75$ & $98.47 \pm 0.96$ & 1.78 and 0.58 \\
\hline $\begin{array}{l}\text { Co-Aprovel @ tablets } \\
\text { (A) } \\
\text { (B) }\end{array}$ & $\begin{array}{l}99.82 \pm 0.57 \\
99.59 \pm 0.88\end{array}$ & $\begin{array}{l}99.43 \pm 0.74 \\
99.68 \pm 0.64\end{array}$ & $\begin{array}{l}1.69 \text { and } 2.02 \\
1.89 \text { and } 0.36\end{array}$ \\
\hline
\end{tabular}

(A): Using the calibration curve method; (B): Using the standard addition

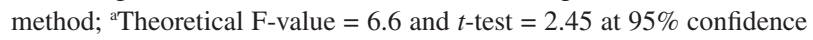
limit for $\mathrm{n}_{1}=4$ and $\mathrm{n}_{2}=4$.

\section{Analysis of spiked human serum}

A quantitative assay of irbesartan spiked in human serum was carried out successfully by the developed SW-AdCSV methods without the necessity for sample pretreatments and/or time-consuming extraction steps prior to the analysis. SW-AdCS voltammograms of various concentrations of irbesartan spiked in human serum (Figure 5) indicated no interfering peaks from endogenous human serum constituents in analysis of irbesartan. Linear relationship of SW-AdCS voltammetric peak current magnitudes $\left(i_{p}\right)$ with concentrations of irbesartan spiked in human serum over the range $7.0 \times 10^{-9}-2.0 \times 10^{-7} \mathrm{~mol} \mathrm{~L}^{-1}$ was obtained (Figure 5, inset); its corresponding regression equation was: $i_{p}(\mu \mathrm{A})=51.70 \mathrm{C}\left(\mu \mathrm{mol} \mathrm{L}{ }^{-1}\right)+0.81(\mathrm{n}=11, \mathrm{r}=0.987)$ Limits of detection (LOD) and quantitation (LOQ) of $2.1 \times 10^{-9} \mathrm{~mol} \mathrm{~L}^{-1}\left(8.99 \times 10^{-4} \mu \mathrm{g} \mathrm{mL}^{-1}\right)$ and $7.0 \times 10^{-9} \mathrm{~mol} \mathrm{~L}^{-1}$ $\left(2.99 \times 10^{-3} \mu \mathrm{g} \mathrm{mL}^{-1}\right)$ irbesartan spiked in human serum was achieved by means of the developed SW-AdCSV method. The results indicated the reliability of the developed 
method for assay of irbesartan in human serum and offer the possibility to assay the drug in real plasma samples at different therapeutic dose levels for pharmacokinetic studies as well as therapeutic drug monitoring.

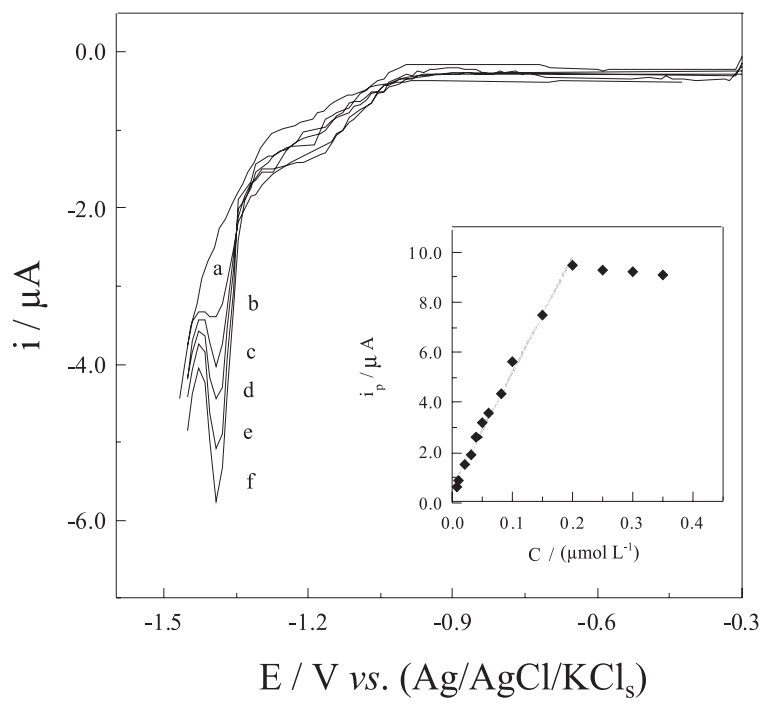

Figure 5. SW-AdCS voltammograms for various concentrations of irbesartan spiked in human serum in the acetate buffer of $\mathrm{pH} 4$ : (a) background; (b) $1 \times 10^{-8}$; (c) $2 \times 10^{-8}$; (d) $3 \times 10^{-8}$; (e) $4 \times 10^{-8}$ and (f) $5 \times 10^{-8} \mathrm{~mol} \mathrm{~L}^{-1} ; \mathrm{t}_{\text {acc }}=110 \mathrm{~s}, \mathrm{E}_{\text {acc }}=-0.3 \mathrm{~V}, \mathrm{f}=120 \mathrm{~Hz}, \Delta \mathrm{E}_{\mathrm{s}}=12 \mathrm{mV}$ and $\mathrm{a}=25 \mathrm{mV}$. Inset: the peak current $\left(\mathrm{i}_{\mathrm{p}}\right)$ versus concentration $(\mathrm{C})$ of irbesartan spiked in human serum.

On the other side, several co-administrated drugs (e.g., aspirin, ibuprofen, metronidazole, hydrochlorothiazide, paracetamol and caffeine) or metal ions (e.g., $\mathrm{Cu}^{2+}, \mathrm{Cd}^{2+}$, $\mathrm{Pb}^{2+}, \mathrm{Ca}^{2+}, \mathrm{Mg}^{2+}, \mathrm{Al}^{3+}, \mathrm{Cd}^{2+}, \mathrm{Fe}^{3+}, \mathrm{Na}^{+}$and $\mathrm{K}^{+}$) did not cause any interference with analysis of the drug by means of the developed SW-AdCSV method.

\section{Pharmacokinetic studies}

A pharmacokinetic study was performed on the plasma samples of two healthy human volunteers following administration of a single oral dose of Aprovel ${ }^{\circledR}$ tablet. Peaks of irbesartan in plasma samples as recorded by SWAdCSV method were of good shape and no additional peak had interfered with that of the analyte. The plasma concentration $v s$. time profiles obtained by means of the developed SW-AdCSV method is shown in Figure 6. The following parameters were assessed for the period of 0-24 $\mathrm{h}$ : area under the plasma concentration-time curves from time zero to the last measurable sample time $\left(\mathrm{AUC}_{0-24}\right)$ and to infinity $\left(\mathrm{AUC}_{0-\infty}\right)$; maximum plasma concentration $\left(\mathrm{C}_{\max }\right)$; time of the maximum concentration $\left(\mathrm{t}_{\max }\right)$; elimination constant $\left(\mathrm{K}_{\mathrm{el}}\right)$ and elimination half-life time $\left(\mathrm{t}_{1 / 2}\right)$, Table 3 . The pharmacokinetic parameters obtained by the developed SW-AdCSV method was in good agreement with those previously reported. ${ }^{1-3}$

Table 3. Pharmacokinetic parameters estimated for two male volunteers (a and b) following an oral administration of a single dose of Aprovel ${ }^{\circledR}$ tablet (150 mg irbesartan) by means of the developed SW-AdCSV method

\begin{tabular}{lcc}
\hline Parameter (unit) & \multicolumn{2}{c}{ Estimated values $^{\mathrm{a}}$} \\
\hline $\mathrm{C}_{\text {max }}\left(\mu \mathrm{g} \mathrm{mL}^{-1}\right)$ & 1.531 & $(\mathrm{~b})$ \\
$\mathrm{t}_{\text {max }}(\mathrm{h})$ & 1.5 & 1.688 \\
$\mathrm{AUC}_{0-24}\left(\mu \mathrm{g} \mathrm{h} \mathrm{mL}^{-1}\right)$ & 13.015 & 1.5 \\
$\mathrm{AUC}_{0-\infty}\left(\mu \mathrm{g} \mathrm{h} \mathrm{mL}^{-1}\right)$ & 14.331 & 13.929 \\
$\mathrm{~K}_{\mathrm{el}}\left(\mathrm{h}^{-1}\right)$ & 0.031 & 15.173 \\
$\mathrm{t}_{1 / 2}(\mathrm{~h})$ & 22.15 & 0.034 \\
\hline
\end{tabular}

${ }^{\mathrm{a}}$ Mean values of two analyses.

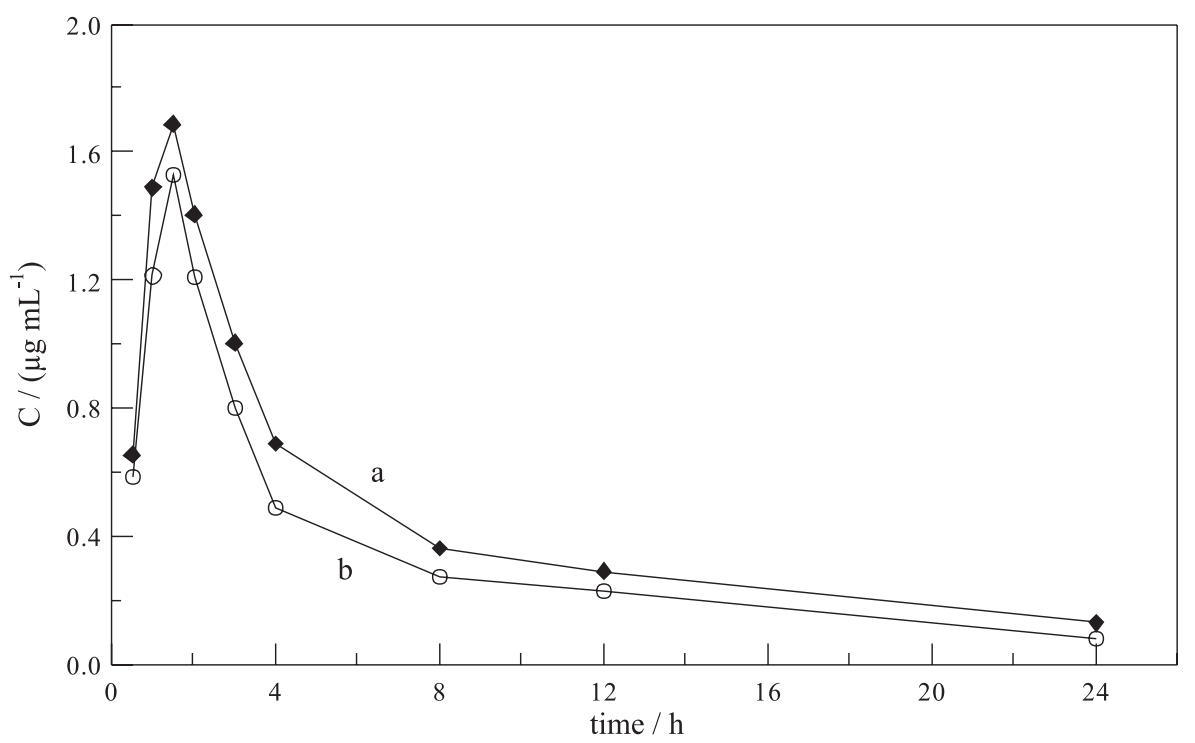

Figure 6. Mean plasma concentration $v s$. time profiles for two male subjects (a and b) following an oral administration of a single Aprovel ${ }^{\circledR}$ tablet $(150$ mg irbesartan), obtained applying the developed SW-AdCSV method. 


\section{Conclusions}

The electroreduction of irbesartan at the mercury electrode in buffered solutions has been studied and discussed. A simple, precise and selective SW-AdCSV method was developed for trace quantification of irbesartan in bulk form, pharmaceutical formulations and human plasma. The developed method showed clear advantages over the reported analytical methods such as short time of analysis, high sensitivity, low price and no necessity for time-consuming extraction steps prior to the analysis. The developed method can be recommended for quantification of irbesartan in quality control and clinical laboratories.

\section{Acknowledgments}

M.M. Ghoneim expresses his gratitude to the Alexander von Humboldt Foundation (Germany) for donating the Electrochemical Analyzer and the Eppendorf centrifuge used in this work. The authors express their gratitude also to Ramadan Specialized Hospital's staff, (Tanta City, Egypt), for the kind care of the two volunteers and for providing the great facilities for collecting and treatments of the plasma samples required for the pharmacokinetic studies.

\section{References}

1. Cazaubon, C.; Gougat, J.; Bousquet, F.; Guiraudou, P.; Gayraud, R.; Lacour, C.; Roccon, A.; Galindo, G.; Barthelemy, G.; Gautret, B.; Bernhart, C.; Perreaut, P.; Breliere, J.-C.; Le Fure, G.; Nisato, D.; J. Pharmacol. Exp. Ther. 1993, 265, 826.

2. Drug Information on irbesartan (AvaproR), http://www.fda.gov/ cder/foi/label/2002/20757s21lbl, accessed in February 2009.

3. Gu, S.; Chen, H.; Qiu, Y.; Shi, S.; Zeng, F.; J. Huazhong Univ. Sci. Technol. Med. Sci. 2002, 22, 14.

4. Caudron, E.; Laurent, S.; Billaud, E. M.; Prognon, P.; J. Chromatogr., B 2004, 801, 339.

5. Erk, N.; J. Chromatogr., B 2003, 784, 195.

6. Shakya, A. K.; Al-Hiari, Y. M.; Alhamami, O. M. O.; J. Chromatogr., B 2007, 848, 245.

7. Chang, S. Y.; Whigan, D. B.; Vachharajani, N. N.; Patel, R.; J. Chromatogr., B 1997, 702,149.

8. González, L.; López, J. A.; Alonso, R. M.; Jiménez, R. M.; J. Chromatogr., A, 2002, 949, 49.

9. Bae, S. K.; Kim, M.-J.; Shim, E.-J.; Cho, D.-Y.; Shon, J.-H.; Liu, K.-H.; Kim, E. Y.; Shin, J. G.; Biomed. Chromatogr. 2009, 23,568 .

10. Ferreirós, N.; Iriarte, G.; Alonso, R. M.; Jiménez, R. M.; Talanta 2007, 73, 748 .

11. Sane, R. T.; Francis, M.; Pawar, S.; Indian Drugs 2002, 39, 32.
12. Kristoffersen, L.; Oiestad, E. L.; Opdal, M. S.; Krogh, M.; Lundanes, E.; Christophersen, A. O. S.; J. Chromatogr., B 2007, $850,147$.

13. Vetuschi, C.; Giannandrea, A.; Carlucci, G.; Mazzeo, P.; Il Farmaco 2005, 60,665.

14. Albero, I.; Ródenas, V.; Soledad, G.; Sánchez-Pedreño, C.; J. Pharm. Biomed. Anal. 2002, 29, 299.

15. Hisham, E. A.; Spectrochim. Acta, Part A 2007, 66, 1248.

16. Erk, N.; Pharmazie 2003, 58, 543.

17. Joseph-Charles, J.; Brault, S.; Boyer, C.; Langlois, M.-H.; Cabrero, L.; Dubost, J.-P.; Anal. Lett. 2003, 36, 2485.

18. Nafisur, R.; Masoom, R. S.; Syed, N. H. A.; Chem. Pharm. Bull. 2006, 54, 626.

19. Gonzalez, L.; Alonso, R. M.; Jimenez, R. M.; Chromatographia 2000, 52, 735 .

20. Bozal, B.; Dogan-Topal, B.; Uslu, B.; Ozkan, S. A.; AboulEnein, H. Y.; Anal. Lett. 2009, 42, 2322.

21. Habib, I. H. I.; Weshahy, S. A.; Toubar, S.; El-Alamin, M. M. A.; Pharm. Chem. J. 2008, 42,438.

22. Pekmez, N. O.; Can, M.; Yildiz, A.; Acta Chim. Slov. 2007, 54, 131.

23. Cakir, S.; Bicer, E.; Odabasoglu, M.; Albayrak, C.; J. Braz. Chem. Soc. 2005, 16, 711.

24. Malik, W. U.; Goyal, R. N.; Jain, R.; J. Electroanal. Chem. 1978, 87, 129.

25. Malik, W. U.; Goyal, R. N.; Talanta 1976, 23, 705.

26. Habib, I. H. I.; Weshahy, S. A.; Toubar, S.; El-Alamin, M. M. A.; Portugaliae Electrochim. Acta 2008, 26, 315.

27. Cagigal, E.; Gonzalez, L.; Alonso, R. M.; Jimenez, R. M.; J. Pharm. Biomed. Anal. 2001, 26, 477.

28. Koldobskii, G. I.; Ostrovskii, V. A.; Gidaspov, B. V.; Chem. Heterocycl. Compd. 1980, 16, 665.

29. March, J.; Advanced Organic Chemistry: Reactions, Mechanisms and Structure, Wiley: New York, 1992.

30. Zuman, P.; The Elucidation of Organic Electrode Processes, Academic Press: New York, 1969.

31. Nicholson, R.S.; Shain, I.; Anal. Chem. 1964, 36, 706.

32. Greef, R.; Peat, R.; Plter, I. M.; Pletcher, D.; Robinson, J.; Instrumental Methods of Analysis in Electrochemistry, E. Horwood: Chichester, 1985.

33. Laviron, E.; Roullier, L.; Degrand, C.; J. Electroanal. Chem. 1980, 112, 11 .

34. Miller, J. N.; Analyst 1991, 116, 3.

35. The USA Pharmacopoeia; The National Formulary, USP 26, Convention Inc. 2003.

36. Ewing, G. W.; Instrumental Methods of Chemical Analysis, $5^{\text {th }}$ ed., Lippincott-Raven: Philadelphia, 1995.

37. Christian, G. D.; Analytical Chemistry, $5^{\text {th }}$ ed., Wiley: Hoboken, NJ 1994.

Submitted: April 25, 2010

Published online: September 21, 2010 